\title{
Standing to Allege Violations of the Doctrine of Specialty: An Examination of the Relationship between the Individual and the Sovereign
}

\author{
Mary-Rose Papandrea $\dagger$
}

In extradition treaties, sovereign powers promise to surrender individuals who have been accused or convicted of an offense outside their territory to the country seeking to prosecute the individual for that offense. Because entering into an extradition treaty involves the sacrifice of some sovereign rights, these treaties are always reciprocal: a state will relinquish its unfettered right to grant asylum to whomever it pleases only if the other parties to the treaty agree to do the same. In addition, extradition treaties contain certain protections that limit the sacrifices these sovereign powers must make. One such restriction that is part of every extradition treaty is the doctrine of specialty. ${ }^{1}$

The doctrine of specialty dictates that once the asylum state extradites an individual to the requesting state under the terms of an extradition treaty, that person can be prosecuted only for the crimes specified in the extradition request. ${ }^{2}$ In United States $v$ Rauscher, the United States Supreme Court held that the specialty doctrine applies to every extradition treaty to which the United States is a signatory, even if specialty is not explicitly mentioned. ${ }^{3}$ Rauscher indicates that an individual extradited to

$\dagger$ B.A. 1992, Yale University; J.D. 1995, The University of Chicago.

1 See United States $v$ Rauscher, 119 US 407 (1886).

2 If the individual comes under the court's jurisdiction outside the scope of the extradition treaty, the defendant cannot claim any of the protections that the treaty might afford. See United States v Alvarez-Machain, 112 S Ct 2188, 2192 (1992); Ker v Illinois, 119 US 436, 443 (1886).

3119 US 407, 422-24, 430 (1886). Although the courts of other countries have also enforced the doctrine of specialty, this Comment only addresses under what circumstances an individual extradited to the United States should have standing to allege a violation of the doctrine. Almost all cases involving the doctrine of specialty in United States courts concern individuals surrendered to the United States. See Note, International Extradition, the Principle of Specialty, and Effective Treaty Enforcement, 76 Minn I Rev 1017, 1018-19 n 15 (1992). In a very small number of cases, defendants surrendered by the United States to another country will attempt to assert the doctrine; however, any holding by a 
the United States has standing to assert the doctrine when the surrendering state also clearly objects to the additional charges not mentioned in the extradition request.. ${ }^{4}$ What remains unclear after Rauscher is under what circumstances an individual has standing to allege a violation of the doctrine when her asylum country does not explicitly object to the additional charge. As a result, courts and commentators continue to debate the scope of standing to allege a violation of the doctrine of specialty.

Different theories of international relations point toward several possible solutions to this issue, and some of these approaches are reflected in current case law. Some courts have granted standing to individuals only when the surrendering state registers an implicit or explicit protest. This position draws on the most traditional theory of international law-political realism-which considers only the relationship between the sovereign states that are signatories to the extradition treaty. ${ }^{5}$ Under this approach, individuals do not have standing to assert violations of international law because international law applies exclusively to states. ${ }^{6}$ The cosmopolitan theory of international relations, on the other hand, would always allow the individual to have standing to assert the doctrine. Cosmopolitan theory posits that international society is most appropriately characterized as a society of individuals, and thus international law should focus on individuals, not states. ${ }^{7}$ With respect to extradition treaties,

United States court on this issue can only be "advisory in character." See Shapiro $v$ Ferrandina, 478 F2d 894, 906 (2d Cir 1973). The extradited individual may assert a violation only in the courts of the country requesting extradition because United States courts have no power to create rights binding in the courts of another country. See Berenguer $v$ Vance, 473 F Supp 1195, 1198 (D DC 1979). Once a defendant is extradited from the United States, she must rely on the intervention of the executive branch to ensure that the doctrine of specialty is followed. See Note, 76 Minn $L$ Rev at 1018-19 n 15.

- When a defendant has standing to assert the doctrine, she essentially has the power to oppose the requesting state's claim to personal jurisdiction over her. See United States $v$ Vreeken, 803 F2d 1085, 1088 (10th $\mathrm{Cir}$ 1986) ("Insofar as a defendant has a right to claim the doctrine's protection, it functions to limit the court's personal jurisdiction over the defendant.").

5 Realism dominated international theory from Thucydides to Machiavelli to Morgenthau. Anne-Marie Slaughter Burley, “At the Bar of World Politics": The Supreme Court and International Law (unpublished manuscript on file with U Chi L Rev). Prominent realists include Hans Morgenthau, Georg Schwarzenberger, E.H. Carr, George Kennan, Reinhold Niebuhr, Arnold Wolfers, and Robert Strausz-Hupé. See Anne-Marie Slaughter Burley, International Law and International Relations Theory: A Dual Agenda, 87 Am J Intl L 205, 207 \& n 5 (1993).

6 P.E. Corbett, Law and Society in the Relations of States 53 (Harcourt, Brace, 1951).

7 Hedley Bull, The Anarchical Society: A Study of Order in World Politics 84:86 (Columbia, 1977). 
cosmopolitan theory assumes that such treaties function to protect individuals against their sovereigns and therefore that individuals are subjects of international law. Some courts have taken an approach that at first glance seems to fall in the middle of these two extreme positions. They allow individuals to assert the doctrine unless the surrendering state explicitly waives it. In fact, however, this "middle position" is just a moderated version of political realism because it emphasizes the will of the sovereigns involved. This approach operates on a presumption that an asylum state's silence is tantamount to an objection.

This Comment argues that in United States courts individuals should have standing to allege violations of the doctrine of specialty only when the surrendering state does not guarantee minimum due process to individuals within its control. This approach rests on liberal international relations theory, also known as liberalism. ${ }^{8}$ Liberalism posits that the central concern in the international law context is the relationship between states and the individuals they represent. ${ }^{9}$ As long as the state adheres to certain minimum standards when dealing with individuals in its domestic affairs, it can be regarded as adequately protecting the interests of those individuals in the international sphere. When this is the case, the United States should respect that state's decision concerning the invocation of the specialty doctrine. However, if the state fails to adequately represent the interests of individuals within its control-whether actually citizens $^{10}$ or merely persons within the territory of that state-extradited defendants should be permitted to assert the doctrine of specialty in United States courts.

${ }^{8}$ Immanuel Kant, John Stuart Mill, Richard Cobden, Woodrow Wilson, Norman Angell, Joseph Schumpeter, and John Maynard Keynes are all noted critics of political realism who have contributed to the development of liberal international relations theory by emphasizing the effects of social equality and political representation on world politics. See Andrew Moravcsik, Liberalism and International Relations Theory 1 (Center for International Affairs, Harvard University, 1993) (Working Paper Series no 92-6) (on file with U Chi L Rev).

9 Id at 3.

10 The United States and other common law countries are generally willing to extradite their own nationals. However, the United States has not always been able to convince other states to agree to do the same. As a result, some United States treaties either do not provide for the extradition of nationals or explicitly forbid it. See Michael Abbell and Bruno Ristau, 4 International Judicial Assistance: Criminal Extradition \$ 13-2-4(6) at 6771 (International Law Institute, 1990) (outlining the different sorts of provisions concerning nationals in U.S. treaties). Recently, however, the United States has concluded three new treaties providing for the extradition of nationals. These treaties replaced old ones that did not so provide. See id §13-1-3(3) at 15. 
Part I of this Comment outlines the historical background and political underpinnings of extradition treaties generally and the doctrine of specialty in particular. Part II outlines some possible approaches to the issue of standing to assert violations of the doctrine of specialty, and their theoretical underpinnings. Part III introduces liberalism and reveals its connection to other doctrines that limit the scope of extradition treaties. This Comment proposes that liberalism can contribute to the development of a coherent theory for the specialty doctrine. As a proxy for determining whether a given state can be trusted to represent the rights of individuals in the international sphere, United States courts should consider whether the surrendering state would provide an adequate alternative forum in the civil litigation context. When the surrendering state would not provide an adequate alternative forum, the individual should have the right to allege a violation of the doctrine of specialty.

\section{INTERNATIONAL LAW AND EXTRADITION}

\section{A. History of Extradition}

Under international criminal law, states have a duty to extradite only individuals accused of a select few international crimes, including war crimes, crimes against peace, and crimes against humanity. ${ }^{11}$ In the absence of an extradition treaty, a sovereign nation enjoys the unrestricted right to grant asylum to whomever it pleases. ${ }^{12}$ The United States Supreme Court recognized this basic tenet of sovereignty in Factor $v$ Laubenheimer, holding that although a state may have a moral duty to extradite a fugitive from justice, there is no legal duty to do so unless the state enters into an extradition treaty so providing. ${ }^{13}$

The United States signed its first extradition treaty with the United Kingdom in 1794, one of almost one hundred new extradition treaties concluded during the eighteenth and early nineteenth centuries. ${ }^{14}$ Today, extradition treaties are the most com-

"Ian Brownlie, Principles of Public International Law 315 \& $\mathrm{n} 97$ (Oxford, 4th ed 1990).

12 Sir Robert Jennings and Sir Arthur Watts, eds, Oppenheim's International Law 950 (Longman, 9th ed 1992). See also Rauscher, 119 US at 412 (stating that according to principles of international law, states are not obligated to surrender fugitives to the state in which their crimes were committed).

13290 US 276, 287 (1933). See also United States $v$ Alvarez-Machain, 112 S Ct 2188, 2194 (1992).

14 Geoff Gilbert, Aspects of Extradition Law 10-11 (Kluwer Academic, 1991). 
mon tool for extracting fugitives from other countries. ${ }^{15}$ However, states may still surrender individuals to other countries with which they do not have an extradition treaty or for offenses not listed in such a treaty solely out of comity. ${ }^{16}$ In addition, states have occasionally extracted an individual from another country by force. Although nations usually respect the territorial integrity of other nations, the United States itself has circumvented at least one extradition treaty by abducting an accused fugitive from another country without that country's consent. ${ }^{17}$

Both the purposes and processes of extradition treaties have evolved considerably in the last two centuries. ${ }^{18}$ Before the eighteenth century, extradition agreements were usually incidental to "treaties of peace and alliance," and often their primary purpose was to guarantee the surrender of political fugitives to their sovereigns. ${ }^{19}$ Today, however, political offenses are no longer extraditable. ${ }^{20}$ In response to the increasing ease and speed with which criminals can seek asylum in another country, extradition agreements during the last two hundred years have come to encompass a growing range of ordinary crimes. ${ }^{21}$ Additionally, although offenses included in these treaties were once strictly

is See id at 8.

${ }^{16}$ See, for example, Fiocconi $v$ Attorney General of United States, 462 F2d 475, 477 (2d Cir 1972). Even in the absence of an extradition treaty, there are a variety of reasons why a country might surrender an individual seeking asylum. For example, a nation might decide for policy reasons to turn over to a wartime ally a traitorous political offender who gave aid and comfort to the nations' common enemy. See Chandler $v$ United States, 171 F2d 921, 935 (1st Cir 1948) (using this scenario as an example). United States law does not permit the executive to grant extradition requests at its discretion: there must be an extradition treaty in place between the United States and the requesting state, or domestic legislation, for the executive to grant such a request. Valentine $v$ Neidecker, 299 US 5, 9 (1936). For example, in 1990 the United States Congress enacted a law that permits the Secretary of State to surrender a United States citizen to another country even if a treaty does not so require. See International Narcotics Control Act of $1990 \S$ 11(a), Pub L No 101-623, 104 Stat 3350, 3356 (1990), codified at 18 USC § 3196 (Supp 1990).

17 See Alvarez-Machain, 112 S Ct at 2197, where the United States Supreme Court held that the abduction of a Mexican national from Mexico to stand trial in the United States did not violate the extradition treaty between the United States and Mexico.

18 There is some evidence of extradition treaties before the eighteenth century. It is generally agreed that the first treaty providing for extradition procedures was between Rameses II of Egypt and the Hittite prince Hattushilish III after Rameses defeated the Hittites in war in 1250 B.C. See Gilbert, Aspects of Extradition Law at 9 (cited in note 14); Ivan A. Shearer, Extradition in International Law 5 (Manchester, 1971).

19 See Shearer, Extradition in International Law at 6; Gerhard von Glahn, Law Among Nations: An Introduction to Public International Law 286 (Macmillan, 6th ed 1992).

20 Id.

21 Id; Gilbert, Aspects of Extradition Law at 1 (cited in note 14). 
construed, nations will now often agree to extradite individuals for lesser included offenses. ${ }^{22}$ Lastly, although extradition was historically a political matter settled by heads of state, by the nineteenth century most states, including the U.S., had involved their judiciaries in the decision whether to comply with extradition requests. ${ }^{23}$

Although states are not obligated to enter into extradition treaties, there are many reasons why they might do so. Some commentators argue that parties to extradition agreements are most concerned with suppressing crimes that both the surrendering and extraditing countries recognize, in order to preserve world public order. ${ }^{24}$ One English court wrote that:

[t]he law of extradition is . . founded upon the broad principle that it is to the interest of civilized communities that crimes, acknowledged to be such, should not go unpunished, and it is part of the comity of nations that one state should afford to another every assistance towards bringing persons guilty of such crimes to justice. ${ }^{25}$

States have a mutual interest in preventing criminals from using territorial boundaries as a shield against their just punishments. ${ }^{26}$ The legal order of each state depends upon the actual enforcement of its criminal processes. As such, states are willing to cooperate in order to preserve peace within their own borders.

Other commentators have focused on states' more selfish motivations for entering into extradition treaties. Some suggest that states agree to surrender accused individuals in part because they are anxious to get rid of foreign criminals. ${ }^{27} \mathrm{~A}$ state

22 Jennings and Watts, eds, Oppenheim's International Law at 962 (cited in note 12).

${ }_{23}$ See Michael P. Shea, Expanding Judicial Scrutiny of Human Rights in Extradition Cases After Soering, 17 Yale J Intl L 85, 88-90 (1992). Two states that retain exclusive executive control over extradition decisions include Spain and Ecuador. Id at $88 \mathrm{n} 11$. In the United States, when a foreign state makes an extradition request a judge reviews the case and makes a recommendation to the Secretary of State, who in her discretion may then issue a warrant for the individual's surrender. See 1 Restatement (Third) of the Foreign Relations Law of the United States $\S 478$ at 582 (1987) ("Restatement of Foreign Relations"); 18 USC § 3184 (1988 \& Supp 1993).

${ }^{24}$ See, for example, Glahn, Law Among Nations at 284 (cited in note 19); M. Cherif Bassiouni, 1 International Extradition: United States Law and Practice 7 (Oceana, 2d ed 1987). See also M. Cherif Bassiouni, International Extradition: A Summary of the Contemporary American Practice and a Proposed Formula, 15 Wayne L Rev 733, 733, 760-61 (1969) (arguing that nations should adopt a less parochial, more international view of criminality).

25 In re Arton, 1 QB 108, 111 (1896).

26 Glahn, Law Among Nations at 284 (cited in note 19).

${ }_{27}$ Georg Schwarzenberger, The Problem of an International Criminal Law, in George 
might also find that in order to prosecute individuals effectively, it makes practical sense to enter into extradition treaties with bordering countries or with countries that would refuse to extradite fugitives without a treaty guaranteeing reciprocal treatment. ${ }^{28}$ Extradition treaties have become a particularly important tool for enforcing laws against crimes of an international nature, such as organized crime, narcotics trafficking, money laundering, and terrorism. ${ }^{29}$ States might also use extradition treaties to solidify close commercial or political ties with each other. In other words, independent sovereign nations may use extradition treaties to create a "mutuality of obligations" that benefits their sovereign interests. ${ }^{30}$ Currently the United States is a party to over one hundred extradition treaties. ${ }^{31}$

Although political concerns have remained the primary motivation for extradition treaties, in recent times nations have become more concerned about the treatment of extradited individuals. In an effort to protect human rights, nations have negotiated for more procedural requirements to ensure that extradited individuals are prosecuted only for offenses considered criminal by the surrendering state or within the scope of the extradition treaty. ${ }^{32}$ The doctrine of specialty is one of the most important of

Keeton and Georg Schwarzenberger, eds, 3 Current Legal Problems 263, 272 (Stevens \& Sons, 1950); Edward M. Wise, Some Problems of Extradition, 15 Wayne L Rev 709, 710-11 (1969) (discussing the hypothesis that states enter into extradition treaties in order to rid themselves of foreign criminals, but then rejecting this argument).

2s Wise, 15 Wayne L Rev at 711.

20 Richard A. Martin, Address Before the Fordham University School of Law (Feb 28, 1991), in Problems in International Law Enforcement, 14 Fordham J Intl L 519, 519 (1990-91). Generally, nations have been quite successful fighting all of these crimes except terrorism, which typically results from internal unrest within a country and thus poses a possible threat to the sovereignty of a nation. Id at 520, 524. States that do not wish to appear as "instruments of a more powerful country, like the United States," have often refused to cooperate with other nations to develop a coherent world policy against terrorism. Id at 525.

3D Bassiouni, 15 Wayne L Rev at 735 (cited in note 24).

31 See 18 USC \& 3181 (1988 \& Supp 1993) (listing extradition treaties to which the United States is a party). The texts of these treaties are reproduced in Igor I. Kavass and Adolf Sprudzs, eds, Extradition Laws and Treaties: United States (Hein, 1980 \& Supp 1987). However, the United States lacks effective extradition treaties with a number of countries. See, for example, United States Department of State, Treaties in Force 147, 207, 224 (1994) (Korea, the Philippines, Saudi Arabia).

${ }_{32}$ Shearer, Extradition in International Law at 13-16 (cited in note 18). For example, two important protections are the double criminality doctrine-which essentially guarantees that the fugitive could be prosecuted for the same crime in her asylum state had the crime been committed there-and the political offense doctrine discussed in text accompanying notes 75-81. See Gilbert, Aspects of Extradition Law at 52-53 (cited in note 14) (discussing double criminality). 
these procedural protections.

\section{B. The Development of the Doctrine of Specialty}

The United States Supreme Court first recognized the doctrine of specialty in United States $v$ Rauscher. In that case, the United States asked Great Britain to extradite William Rauscher, an officer on an American vessel at the time of his alleged crimes, to stand trial on a charge of murder on the high seas. Great Britain agreed. Once Rauscher arrived in the United States, however, he was also charged with infliction of cruel and unusual punishment-a charge not included in the extradition request. $^{33}$

The United States's request for the extradition of Rauscher was made pursuant to an extradition treaty between the United States and Great Britain. Although this treaty enumerated certain offenses for which an individual could be extradited, it did not explicitly stipulate that an extradited individual could only be charged with the crimes indicated in the extradition request. However, the Supreme Court held that the specific enumeration of extraditable offenses made it clear that the countries could not charge an individual with any other offenses:

It is unreasonable that the country of the asylum should be expected to deliver up such person to be dealt with by the demanding government without any limitation, implied or otherwise, upon its prosecution of the party. ${ }^{34}$

The Court's announcement that this "limitation," later called the doctrine of specialty, was implicit in the United States-United Kingdom extradition treaty was hardly a magnanimous gesture to the British. The United States had a pragmatic reason to abide by the doctrine of specialty: if it followed the doctrine, it would be more likely that nations seeking extradition of persons from the United States would prosecute them only within reasonable limits. In fact, since Rauscher, all United States extradition treaties have explicitly included the doctrine of specialty, thus eliminating the need for courts to read the doctrine into treaties.

The Rauscher Court was unclear as to whether a defendant has standing to assert a violation of the doctrine of specialty, or

${ }^{33}$ Rauscher, 119 US at 409.

34 Id at 419.

${ }_{35}$ See Abbell and Ristau, 4 International Judicial Assistance: Criminal Extradition § 13-2-4 at 76-77 (cited in note 10). 
whether that right lies solely with the surrendering state. According to the Court, the doctrine of specialty is a right accorded to defendants pursuant to formal extradition proceedings. The Court held that treaties may "contain provisions which confer certain rights upon the citizens . . . which are capable of enforcement as between private parties in the courts of the country."36 Treaty provisions that concern individual rights are judicially enforceable because under the United States Constitution, treaties are "the supreme Law of the Land": ${ }^{37}$ their provisions must be treated just as the provisions of any statute. ${ }^{38}$ However, even though the Rauscher Court referred to the doctrine as the defendant's "right," it did not determine whether this right is independently enforceable absent support from the surrendering country, from which the defendant's treaty rights are derived. ${ }^{39}$

At a minimum, the facts of Rauscher indicate that when the asylum country registers a formal, or even implicit, protest to additional charges, the individual has standing to raise this objection. Although in Rauscher the defendant himself asserted the doctrine, he did so with the implicit support of Great Britain, his asylum country. In a previous case involving a fugitive named Winslow, Great Britain had refused to grant the United States's extradition request without a "preliminary pledge" from the United States government that it would not prosecute him for any crimes other than forgery, the offense for which extradition was demanded. ${ }^{40}$ Given the recent and extensive diplomatic negotiations concerning the application of the doctrine of specialty to this extradition treaty in the case of Winslow, it was reasonable for the Court to assume that Great Britain would have objected to the additional charges made against Rauscher. ${ }^{41}$ Still, Rauscher left open the issue of whether an individual should have standing when her asylum state does not formally or implicitly allege a violation of the doctrine.

${ }^{35}$ Rauscher, 119 US at 418, quoting the Head Money Cases, 112 US 580, 598 (1884).

37 US Const, Art VI, cl 2.

33 Rauscher, 119 US at 419.

39 Even courts that believe defendants should be given broad standing rights concede that any rights defendants obtain from treaties are derivative in nature. See, for example, Leighnor v Turner, 884 F2d 385, 389 (8th Cir 1989).

${ }^{40}$ Rauscher, 119 US at 415.

41 See Ford v United States, 273 US 593, 615 (1926) (Rauscher "was decided at the end of a prolonged controversy between Great Britain and the United States through their State Departments"); United States v Kaufman, 858 F2d 994, 1008-09 (5th Cir 1988) (noting same). 


\section{CuRrent ApProaches to tHe ISSUE OF Standing to ALLEGE VIOLATIONS OF THE SPECIALTY DOCTRINE}

Some courts hold that only the surrendering state can object to violations of the doctrine of specialty: the individual lacks the power to raise the issue on her own. Others have contended that individuals can assert the doctrine as long as the surrendering state does not expressly waive its right to object to the charges. A third possible approach suggests that individuals should always have the right to assert the doctrine, even if the surrendering state expressly consents to its violation. The conflict among these approaches fundamentally rests on a theoretical disagreement about the position of individuals in international law.

\section{A. Political Realism: Only the Asylum State Can Assert a Specialty Violation}

Some circuit courts have decided that the defendant has standing to assert the doctrine of specialty only if the surrendering state itself objects in some way. ${ }^{42}$ This approach to the doctrine of specialty rests on the theory of international relations called political realism.

Realists believe that the goal of international law is to maintain peace and stability between nations. ${ }^{43}$ The realist theory is often conceptualized as the "billiard ball model" of international relations because it views states as formally and functionally identical and opaque with regard to their domestic and statesociety relations. ${ }^{44}$ Individuals play no role in this model, and accordingly, they can derive very few rights from treaties. Unless a treaty explicitly provides individuals with enforcement rights, such rights do not exist. ${ }^{45}$

42 The Second, Fifth, and Seventh Circuit Courts of Appeals have taken this position. See United States v DiTommaso, 817 F2d 201, 212 (2d Cir 1987); Shapiro v Ferrandina, 478 F2d 894, 905 (2d Cir 1973); United States v Kaufman, 874 F2d 242, 243 (5th Cir 1989); United States $v$ Munoz-Solarte, 1994 US App LEXIS 18128, $* 3$ (7th Cir). The Sixth Circuit also has indicated that it would follow a restrictive approach to standing. See Demjanjuk v Petrovsky, 776 F2d 571, 583-84 (6th Cir 1985) (citing Shapiro and stating that "there is a serious question. whether [the defendant] has standing to assert the principle of specialty").

${ }^{43}$ Fernando R. Tesón, The Kantian Theory of International Law, 92 Colum L Rev 53, 72-74 (1992).

44 Arnold Wolfers first used the phrase "billiard ball model" to describe realist political theory. See Arnold Wolfers, Discord and Collaboration: Essays on International Politics 19-24 (Johns Hopkins, 1962).

${ }_{45}$ See Note, 76 Minn L Rev at 1021 (cited in note 3). 
Realists argue that because sovereign states have no duty to surrender individuals to another state in the absence of an extradition treaty, but rather have an absolute right to grant asylum, the doctrine of specialty is needed "to protect the extraditing government against abuse of its discretionary act of extradition." ${ }^{36}$ When a state enters into an extradition treaty, it sacrifices a limited portion of its right to grant asylum to the accused individual. ${ }^{47}$ Under the realist view, the doctrine of specialty functions to protect the remaining sovereign rights of the asylum state, which continue to immunize the defendant from prosecution for those acts not covered by the extradition request. When an asylum state waives the doctrine of specialty, it effectively denies the extradited individual asylum for any additional crimes. Because a sovereign state reserves the right to grant or deny asylum, the individual is at the state's mercy. An extradition treaty does not give a defendant a greater right to demand asylum than she would have had without an extradition treaty. ${ }^{48}$

Although there is no consensus on exactly what motivates sovereign parties to enter into extradition agreements, realists contend that states enter into extradition agreements only to serve their own interests, and not the interests of accused individuals. One court has noted that:

[a]s a matter of international law, the principle of specialty has been viewed as a privilege of the asylum state, designed to protect its dignity and interests, rather than a right accruing to the accused. ${ }^{49}$

According to this view, treaties function simply as contracts between sovereign states designed to further the interests of each signatory. Parties perform their contractual duties because they have faith that the other party will reciprocate. Because specialty

46 United States $v$ Paroutian, 299 F2d 486, 490 (2d Cir 1962).

47 See Jaffe $v$ Smith, 825 F2d 304, 306 (11th Cir 1987). See also Rauscher, 119 US at 411-12 ("Prior to these treaties, and apart from them . . . there was no well-defined obligation on one country to deliver up such fugitives to another, and though such delivery was often made, it was upon the principle of comity, and within the discretion of the government whose action was invoked; and it has never been recognized as among those obligations of one government towards another which rest upon established principles of international law.").

4* See Ker $v$ Illinois, 119 US 436, 442 (1886). In Ker, the Supreme Court rejected the defendant's contention that an extradition treaty creates a right not to be taken from the asylum state outside the terms of the treaty. Id at $441-42$.

19 Shapiro, 478 F2d at 906. 
is intended to serve the interests of the asylum state, the benefits the doctrine confers on individual defendants are purely secondary and incidental. ${ }^{50}$ Under this contract analogy, extradited individuals are essentially third-party beneficiaries of extradition treaties: their rights are derived exclusively from the rights of the surrendering sovereign. Thus, when the surrendering nation fails to assert the doctrine, it waives not only its own rights but the derivative rights of the individual as well. For realists, the doctrine of specialty is a right created by the state that can be denied by the state: it is by no means a fundamental right embedded in natural law.

At a minimum, the most stringent realist approach to the doctrine of specialty-denying an individual standing unless the asylum state expressly objects-is inconsistent with Rauscher. Although the Rauscher Court did not openly discuss the issue of standing, it granted the defendant standing to assert a specialty violation even though his asylum country only implicitly objected. Therefore, to be consistent with Rauscher, realists must at least concede standing to defendants when the surrendering state implicitly or explicitly alleges a specialty violation.

But even if realists were to make this concession it would not be enough. Construing treaties as mere contracts oversimplifies them. ${ }^{51}$ In Rauscher, the Court repeatedly referred to the doctrine of specialty as a right of both the extraditing nation and the extradited defendant. ${ }^{52}$ Although the defendant's specialty rights clearly derive from those of the asylum state, the language of the Rauscher decision indicates that a defendant is more than just a third-party beneficiary to the treaty: the individual's rights are at the heart of the specialty doctrine. Thus, to concentrate solely on the rights of the asylum state misconstrues the doctrine's essential nature. A comprehensive theory of the specialty doctrine must take into account the rights of both the surrendering state and the extradited individual.

so Id.

51 Indeed, many of the fundamental tenets of contract law do not apply in the case of treaties. For example, a state often cannot escape its treaty violations by claiming it was coerced to enter into the treaty. This makes sense because many treaties, especially peace treaties, are the product of direct, or at least indirect, coercion. Thomas M. Franck and Michael J. Glennon, Foreign Relations and National Security Law 243 (West, 1987). Consideration also plays no important role in treaty formation. Id. Furthermore, a state cannot claim that an internal law prevents it from fulfilling its treaty obligations, except under very limited circumstances. Id.

52119 US at $419,422$. 
B. Moderated Political Realism: Defendants Have Standing absent Express Waiver of Specialty by the Asylum State

The Third, Eighth, Ninth, Eleventh, and D.C. Circuits apply an explicit waiver approach. ${ }^{53}$ Under this approach, courts inquire whether the surrendering state could have asserted a specialty violation and allow defendants to make those same objections unless the surrendering state explicitly waives the doctrine. Although this approach appears to consider both individual and state rights, it is also grounded in political realism.

Like those who argue that the surrendering state must explicitly or implicitly object, those who support this approach argue that the extraditee's standing to assert the doctrine is only derivative: the extraditee may object only to breaches to which the surrendering country would have been entitled to object. ${ }^{54}$ Advocates of this approach believe that the protections afforded by the specialty doctrine "exist... only to the extent that the surrendering country wishes. ${ }^{n 5}$ Thus, like the restrictive approach outlined in Section II.A., political realism provides the theoretical basis for this slightly more moderate position because of the exclusive focus on the asylum state's interests.

The only difference between this approach and the stricter realist position presented above is that under this moderated approach, the surrendering nation need not make any express or implicit objection before the extraditee can raise the doctrine of specialty as a defense; it is sufficient that the surrendering nation might have raised the same objections. ${ }^{56}$ This position assumes that silence on the part of the surrendering state essentially amounts to an objection, ${ }^{57}$ and thus allows the extradited

5 See United States $v$ Riviere, 924 F2d 1289, 1301 (3d Cir 1991); Leighnor v Turner, 884 F2d 385, 389 (8th Cir 1989); United States v Thirion, 813 F2d 146, 151 \& n 5 (8th Cir 1987); United States $v$ Cuevas, 847 F2d 1417, 1426 (9th Cir 1988); United States $v$ Najohn, 785 F2d 1420, 1422 (9th Cir 1986); United States v Diwan, 864 F2d 715, 721 (11th Cir 1989); United States v Herbage, 850 F2d 1463, 1466 n 7 (11th Cir 1988); United States $v$ Sensi, 879 F2d 888, 895 (DC Cir 1989). See also Comment, Standing for the Doctrine of Specialty in Extradition Treaties: A More Liberal Exposition of Private Rights, 25 Loyola LA L Rev 1377, 1386 (1992); Note, 76 Minn L Rev 1017 (cited in note 3); Note, Individual Rights and the Doctrine of Speciality: The Deterioration of United States v. Rauscher, 14 Fordham Intl L J 987, 1002 \& n 79 (1990).

st Leighnor, 884 F2d at 389; Najohn, 785 F2d at 1422.

so Najohn, $785^{\circ}$ F2d at 1422, citing Shapiro v Ferrandina, 478 F2d 894, 906 (2d Cir 1973).

of Najohn, 785 F2d at 1422.

57 One commentator argues that in Rauscher the Supreme Coturt assumed that Great Britain's silence meant that it objected to the additional charges against Rauscher. See Note, 76 Minn L Rev at 1031 (cited in note 3). 
defendant to assert the doctrine when the state is silent in order to protect the state's interests. However, once the surrendering state expressly consents to the additional charges, the defendant loses standing to assert the doctrine. The inquiry under this moderate approach focuses on the surrendering state just as the inquiry under strict political realism does. In both cases, the defendant's rights are limited to and defined by the interests of the surrendering state.

Supporters of the moderate approach argue that political factors and the desire for efficient treaty enforcement support the defendant's right to standing. A state may decide not to protest because it faces political pressure to ignore the situation. ${ }^{58}$ An individual would then be able to assert the doctrine without her asylum nation sacrificing its national interests. Advocates for this position also make the practical argument that, because it is difficult for a foreign state to keep track of proceedings after it has extradited an individual, it is more efficient to let the individual assert the doctrine. ${ }^{59}$

Because this approach is grounded in realism, it has the same fundamental flaws as the stricter realist approach discussed in Section II.A. In addition, this approach has its own unique problems. First, just as states are sometimes under pressure not to raise a specialty objection, they can also be pressured to waive the doctrine entirely; if this is the case, this moderated realist approach would accord the individual defendant no recourse. Second, by allowing an individual to hold up a prosecution whenever the extraditing government is officially silent regarding the additional charges, this approach may allow defendants to assert the doctrine even in cases where two governments agree for perfectly legitimate reasons that the requesting state should conduct a prosecution for offenses whether or not they are named in the formal extradition request. To require formal consent whenever the extraditing country wishes to press additional charges would place a heavy administrative burden on both parties. Because nations commonly expand the scope of their agreements, a requirement of formal consent in every case would often run counter to the mutual interests of the countries involved. In

53 See id at $1038 \mathrm{n} 96$ (arguing that "[b]ecause the only practical remedies for the surrendering state are to lodge a diplomatic protest or to deny the next extradition request, either of which may create or heighten political tension between the countries, it is unlikely to protest the more routine treaty violations").

s9 Id at 1039 . 
its attempt to correct some of the flaws in the strict realist approach, this moderated approach creates new problems of its own.

C. Cosmopolitan Theory: Defendants Have an Unequivocal Right to Standing

The cosmopolitan theory of international law suggests that individuals should always have the right to assert the doctrine of specialty, even if the asylum country expressly waives its rights under an extradition treaty. Rather than conceptualizing international law as a conflict between sovereign states, cosmopolitans view individuals as subjects of international law who can derive rights directly from it. ${ }^{60}$ Accordingly, an individual need only show that she was the intended beneficiary of the extradition treaty in order to have standing to assert a violation of the treaty. ${ }^{61}$ No matter what the surrendering sovereign says or does, the terms of the treaty cannot be waived.

The cosmopolitan approach draws on the finding in Rauscher that extradition treaties are self-executing: they do not require the aid of instituting legislation to become effective. ${ }^{62}$ It also finds support in one of the primary purposes of the doctrine of specialty, to secure some protections for an extradited individual. Cosmopolitans give individuals complete control over the exercise of this right because fundamentally they distrust the state's ability to make an appropriate judgment between individual rights and state authority.

Although the cosmopolitan approach may at first appear attractive, it has a number of significant problems. First, this approach confuses the question of whether a treaty is self-executing with the question of whether a party has standing to enforce its terms. ${ }^{63}$ For example, a treaty could include the doctrine of

is See Glahn, Law Among Nations at 235-49 (cited in note 19) (discussing the emergence of the individual as a subject of international law in the human rights context); Manuel R. García-Mora, International Law and Asylum as a Human Right 13-15 (Public Affairs, 1956) (discussing individuals as subjects of international law under natural law theory).

${ }_{61}$ See Warth $v$ Seldin, 422 US 490, 500 (1975) ("Essentially, the standing question [depends on] whether the constitutional or statutory provision on which the claim rests properly can be understood as granting persons in the plaintiff's position a right to judicial relief.").

${ }_{62}$ See Rauscher, 119 US at 418-19.

œ 1 Restatement of Foreign Relations $\$ 111$ comment $h$ (cited in note 23) ("Whether a treaty is self-executing is a question distinct from whether the treaty creates private rights or remedies."). See also Cook v United States, 288 US 102, 121-22 (1933); Head 
speciality but explicitly provide that individuals cannot assert it without the consent of their asylum state. The provision providing for the doctrine of speciality would be self-executing but the extradited individual would have no right to assert it on her own. Ordinarily, claims for violation of an international obligation may be made only by the state to whom the obligation is owed. ${ }^{64}$ States recognize that individuals have rights in the first instance, but individuals are deemed to have delegated the protection of these rights to their governments vis-à-vis other governments, as long as their governments protect their rights at home.

Second, the cosmopolitan approach fails to recognize that the doctrine of specialty does not just serve to protect the individual; it is first and foremost part of the bargain states have made to protect their sovereign interests. ${ }^{65}$ Even when an extradition treaty is in place, sovereign powers retain discretionary power to surrender fugitives to one another under circumstances not outlined in the relevant treaty. ${ }^{66}$ Individuals do not have a right to asylum; rather, the grant of asylum and immunity lies solely in the providence of the sovereign state. ${ }^{67}$ Therefore, it would undermine the relationship between sovereign states to permit defendants to allege violations of specialty even when their asylum state explicitly waives it. The defendant should not have standing unless there are special circumstances in her asylum state that lead the federal court to believe that its failure to assert the specialty doctrine is somehow illegitimate.

\section{APPLYING LIBERAL INTERNATIONAL RELATIONS THEORY TO THE ISSUE OF STANDING}

This Part introduces liberalism as a theory of international law and illustrates its influence in several other areas of United States extradition law. This Comment then argues that courts

\footnotetext{
Money Cases, 112 US 580, 598-99 (1884).

642 Restatement of Foreign Relations $\S 902$ comment a (cited in note 23). See also id $\S 906$ comment a.

65 See Gilbert, Aspects of Extradition Law at 107 (cited in note 14) (stating that the cosmopolitan approach "may be a sensible progression" but that "it does seem to go against the spirit of the principle of specialty which is to treat it as part of the bargain between states, as well").

${ }^{66}$ See Glahn, Law Among Nations at 313-14 (cited in note 19); United States $v$ Alvarez-Machain, 112 S Ct 2188 (1992).

67 See Glahn, Law Among Nations at 303-13 (cited in note 19) (discussing circumstances in which governments have historically chosen to grant asylum); Note, The Principle of Specialty: A Bifurcated Analysis of the Rights of the Accused, 29 Colum $\mathrm{J}$ Transnatl L 407, 412 (1991) (rejecting the claim that individuals have a right to asylum).
} 
should grant defendants standing to allege specialty violations only when the surrendering state cannot be considered an adequate representative of individual interests in the international sphere. In order to make this determination, United States courts should inquire whether the surrendering state would constitute an adequate alternative forum-that is, whether the surrendering state in its domestic affairs adequately guarantees minimum due process rights. Such an inquiry can serve as a proxy determination of the nation's ability to protect individual rights in the international sphere. The goal of this approach is to reach an appropriate balance between the rights of the surrendering state and the rights of the extradited individual.

\section{A. Liberal International Relations Theory}

Liberal international relations theory offers a conceptual middle ground between realists and cosmopolitan theorists. Liberalism posits that international relations are driven by a conceptually prior set of relationships between the individuals and groups in domestic society and the state itself. ${ }^{68}$ Liberals see states as formed as the result of a social contract-in which individuals recognize the value of establishing an autonomous state authority that is then entitled to exercise power over them so long as their fundamental rights are preserved. This contract is the guarantee of social order; the state must thereafter establish a balance between the need to protect the individual and the need to preserve that order. Liberalism recognizes that the state is still the primary actor in international relations, but maintains that in order for international law to function properly in the protection of human rights, the state must be a trustworthy representative of the interests of its individuals. ${ }^{69}$ Ideally, each state serves as an agent in the international realm in order to protect the individual.

According to liberal theory, when states conclude extradition treaties they are in effect agreeing to assist each other as long as each can be sure that the other will in fact protect the rights of the individuals within its control. ${ }^{70}$ The United States courts,

68 See Moravcsik, Liberalism and International Relations Theory at 3 (cited in note 8) "Society' should be understood as 'an aggregate of autonomous individuals and voluntary groups with pre-political interests . . . separate from and prior to the nation-state." Id at 11. The interests of individuals are represented through political institutions and social practices bridging the gap between society and state. Id.

See Slaughter Burley, 87 Am J Intl L at 227 (cited in note 5).

70 See Glucksman $v$ Henkel, 221 US 508, 512 (1911) ("We are bound by the existence 
then, should respect a state's decision to assert treaty violations if the foreign government can be trusted to protect the rights and interests of the individuals within its control.

Whether a foreign government adequately represents individuals' interests in its dealings with other states is a difficult inquiry. However, determining whether the state adheres to certain minimum standards in the treatment of individuals in its domestic affairs is an appropriate proxy. If the state guarantees minimum human rights in domestic affairs, then it can be regarded as a valid representative of these individuals in international affairs. When this is the case, United States courts should respect the state's decision whether to allege treaty violations. However, liberal theory recognizes that asylum countries will not always protect the human rights of requested individuals, particularly when the relationship between a state and its individuals has changed since the extradition treaty was signed. It is generally assumed that the United States does not enter into extradition treaties with countries that do not respect human rights. ${ }^{71}$ However, not all governments are stable. Occasionally, the domestic situation in a once trustworthy country changes so dramatically that it no longer protects fundamental rights as it once did, ${ }^{72}$ even though the extradition treaty is technically still in effect. ${ }^{73}$ When the relationship between a state and its individuals becomes unsatisfactory, defendants should have standing to assert violations of international law even if their asylum country expressly waives its right to do so. Although "liberal states" may be broadly defined as "states with juridical equality, constitution-

\footnotetext{
of an extradition treaty to assume that the trial will be fair.").

${ }^{71}$ See, for example, Ahmad v Wigen, 726 F Supp 389, 411 (E D NY 1989). This assumption has merit. There is evidence that the United States has in the past refused to enter into international human rights treaties because they did not offer as much protection as its domestic law. See Dean Rusk, A Personal Reflection on International Covenants on Human Rights, 9 Hofstra L Rev 515, 520 (1981). See also Additional Views, Extradition Act of 1984, HR Rep No 998, 98th Cong, 2d Sess 61 n 19 (1984) (citing Senate's refusal to consent to extradition treaty with the Philippines based on human rights concerns).

${ }^{72}$ See, for example, Ker $v$ Illinois, 119 US 436 (1886). Ker involved an extradition treaty between the United States and Peru. A United States agent went to Peru with an extradition warrant for Ker that he intended to present to local authorities. However, when he arrived in Lima, he found that the city was in political chaos-it had been taken over by the military forces of Chile. The agent then decided to bypass the formal extradition procedures completely and simply abducted Ker and brought him back to the United States for prosecution. See Charles Fairman, Ker v. Illinois Revisited, 47 Am J Intl L 678 (1953) (providing historical facts not provided in the Ker opinion itself).

${ }^{73}$ See Bassiouni, 1 International Extradition at 41 (cited in note 24) (stating that "a change in government does not abrogate a treaty").
} 
al protections of individual rights, representative republican governments, and market economies based on private property rights, ${ }^{374}$ other forms of government that do not meet these criteria may also be deemed to protect the interests of their citizens under certain circumstances.

B. Current Extradition Practices Reflect the Principles of Liberalism

Liberalism is not an abstract legal theory with little relevance to current law. In fact, liberal theory provides a coherent explanation of several current extradition practices. The political offense exception and the frequency with which courts inquire into the domestic affairs of other nations during extradition hearings provide two such examples. These practices illustrate that United States courts routinely investigate the relationship between other nations and individuals under their control before they will respect an agreement made between sovereign powers. This sort of inquiry is the essence of the liberal approach.

\section{The political offense doctrine.}

Although the first extradition treaties were primarily intended to secure the return of fugitives who had committed political crimes against their sovereigns, today political crimes are no longer extraditable. ${ }^{75}$ Under the political offense doctrine, parties to extradition treaties may refuse extradition requests when the asylum nation regards the alleged offense as one of political character. Although the United States does not have a statute formalizing this exception to extradition, modern extradition treaties to which the United States is a party commonly provide for this exception explicitly. ${ }^{76}$

For the purposes of extradition, a political offense is often defined as "an offense committed in the course of and incidental to a violent political disturbance, such as war, revolution, and rebellion." ${ }^{\text {77 }}$ However, the offense must not only be incidental to

74 Anne-Marie Burley, Law Among Liberal States: Liberal Internationalism and the Act of State Doctrine, 92 Colum L Rev 1907, 1909 (1992).

75 See Glahn, Law Among Nations at 286 (cited in note 19).

76 See, for example, Escobedo $v$ United States, 623 F2d 1098, 1104 (5th Cir 1980) (discussing the United States-Mexico extradition treaty).

7 Id. See also Ornelas $v$ Ruiz, 161 US 502, 511-12 (1896); In re Extradition of Gonzalez, 217 F Supp 717, 720-21 (S D NY 1963); Eain $v$ Wilkes, 641 F2d 504, 514 (7th Cir 1981). 
or form a part of a political disturbance, but also be in furtherance of one side or another in a bona fide struggle for political power. ${ }^{78}$ Courts have labeled the following offenses as nonextraditable political offenses: hijacking a plane to obtain freedom; assassination or attempted assassination of important public figures; planting bombs to gain attention or support for a political cause; and robbery committed to obtain funds for a political movement. ${ }^{79}$ For example, in United States $v$ Doherty, a United States magistrate refused to grant the United Kingdom's request for the extradition of a member of the Provisional Irish Republican Army who fled from charges that he killed a British soldier. ${ }^{80}$ The extradition magistrate held that this was a political offense and thus not extraditable under the treaty between the United States and Great Britain. ${ }^{81}$

The primary purpose of the political offense doctrine is to protect the due process rights of the individual. Asylum states do not want to extradite an individual when it is likely that the prosecution in the requesting country will be unfair. United States courts are willing to exercise this doctrine even though to do so may at times place them in a politically uncomfortable position. The political offense exception thus reflects liberal theory because it is essentially concerned not with the relationship between the states involved in the international sphere, but with the domestic relationship between individuals and the state. When there is reason to believe that the state cannot be trusted to protect the rights of individuals, the political offense doctrine demands that United States courts refuse extradition requests.

\section{Erosion of the noninquiry rule.}

Under the tradition rule of noninquiry, courts determining whether a defendant is extraditable may not examine the political or judicial system of the requesting state. ${ }^{82}$ However, many courts and commentators have recognized that serious substantive or procedural due process concerns may occasionally necessi-

78 See Escobedo, 623 F2d at 1104; Karadzole v Artukovic, 170 F Supp 383, 392 (S D Cal 1959). This requirement that there be a nexus between the act and the uprising has been interpreted liberally. See Quinn v Robinson, 783 F2d 776, 809-10 (9th Cir 1986).

${ }^{79}$ See 1 Restatement of Foreign Relations $\$ 476 \mathrm{n} 4$ (cited in note 23 ).

so 786 F2d 491 (2d Cir 1986).

81 Id at 494 .

${ }^{82}$ For a defense of the traditional, strict noninquiry rule, see Jacques Semmelman, Federal Courts, the Constitution, and the Rule of Non-Inquiry in International Extradition Proceedings, 76 Cornell L Rev 1198 (1991). 
tate judicial review of the domestic affairs of other countries. ${ }^{83}$ Like the political offense exception, such inquiries reflect liberalism's emphasis on the primacy of the relationship between the sovereign and the individual.

Some treaties contain provisions specifically authorizing courts to refuse extradition requests when it is unlikely the defendant would receive a fair trial in the tribunal of the requesting nation. For example, the treaty between the United States and the United Kingdom provides that extradition is prohibited "if the person sought establishes ... by a preponderance of the evidence that ... he would, if surrendered, be prejudiced at his trial or punished, detained, or restricted in his personal liberty by reason of his race, religion, nationality, or political opinions." ${ }^{84}$

The "noninquiry rule" originated in 1901 when the Supreme Court in Neely $v$ Henkel held that Americans prosecuted abroad were not entitled to all the protections afforded by United States procedural requirements. ${ }^{85}$ The Court held that the defendant had no right to a trial "in any other mode than that allowed to its own people by the country whose laws he has violated and from whose justice he has fled." ${ }^{186}$ Proponents of the noninquiry rule argue that United States courts should not question the quality of a nation's court system or the motives behind its decision to extradite. ${ }^{87}$ This position assumes that because the United States entered into an extradition agreement with the requesting country, that country will provide a fair trial. ${ }^{88}$ Strict interpreters of the noninquiry rule argue that courts must trust the Secretary of State to intervene to prevent the extradition if she believes it necessary to prevent an injustice. ${ }^{89}$

Current law indicates that the noninquiry rule is not as absolute as it may have once been. Lower courts and commenta-

sa See 1 Restatement of Foreign Relations $\$ 476$ comment h (cited in note 23 ).

\& Supplemental Extradition Treaty with the United Kingdom (June 25, 1985), USUK, Art 3, II a, S Exec Rep 99-17, 99th Cong, 2d Sess 16 (1986).

* 180 US 109, 122-23 (1901). See also Glucksman v Henkel, 221 US 508, 512 (1911); In re Extradition of Burt, 737 F2d 1477, 1485 \& n 11 (1984).

180 US at 123.

B7 In re Howard, 996 F2d 1320, 1329-30 (1st Cir 1993); United States v Martinez, 755 F Supp 1031, 1036-37 (N D Ga 1991).

83 See, for example, Glucksman, 221 US at 512 ("We are bound by the existence of an extradition treaty to assume that the trial will be fair.").

${ }^{*}$ See Ahmad v Wigen, 726 F Supp 389, 411 (E D NY 1989). See also In re Extradition of Tang Yee-Chun, 674 F Supp 1058, 1068 (S D NY 1987) (finding that it is the function of the Secretary of State, not the courts, to determine whether extradition should be avoided for humanitarian reasons). 
tors have suggested that exceptions to the noninquiry rule are essential when the fundamental minimal due process rights of the accused are in danger..$^{90}$ In Gallina $v$ Fraser, the Second Circuit stated that it could "imagine situations where [a defendant], upon extradition, would be subject to procedures or punishments so antipathetic to a federal court's sense of decency as to require reexamination of the [noninquiry rule]. ${ }^{.91}$ Although a country may have guaranteed minimum due process protections at the time an extradition treaty was signed, it is possible that at the time of its enforcement that country no longer offers such protections. When this happens, it is important that courts take an active role in protecting minimum human rights, rather than leaving this role solely to the Secretary of State. ${ }^{92}$ The fear is that the Secretary of State would sacrifice the rights of individuals in the name of foreign policy: "For obvious reasons of state, our diplomats are rarely eager to label foreign governments unjust, particularly when military and economic advantages hang in the balance. ${ }^{93}$ Furthermore, not only are courts more willing to make such highly political decisions about another state's good faith or due process procedures, the potential embarrassment to United States foreign policy is minimalized because of the relatively insulated nature of judicial decisions. ${ }^{94}$

${ }^{9}$ See, for example, Ahmad, $726 \mathrm{~F}$ Supp at 412-20. See also Gill $v$ Imundi, $747 \mathrm{~F}$ Supp 1028, 1048-50 (S D NY 1990); Comment, The Tension between Policy Objectives and Individual Rights: Rethinking Extradition and Extraterritorial Abduction Jurisprudence, 41 Buff L Rev 627, 631 (1991); John G. Kester, Some Myths of United States Extradition Law, 76 Georgetown I J 1441, 1492 (1988).

${ }_{91} 278$ F2d 77, 79 (2d Cir 1960). See also Demjanjuk v Petrovsky, 776 F2d 571, 583 (6th Cir 1985), quoting Gallina, 278 F2d at 79 (holding that the court would not inquire into the procedures of the extraditing nation unless they were found to be "antipathetic to a federal court's sense of decency"); Sahagian v United States, 864 F2d 509, 514 (7th Cir 1988), quoting Burt, $737 \mathrm{~F} 2 \mathrm{~d}$ at 1487 (stating that inquiry into "particularly atrocious procedures or punishments employed by the foreign jurisdiction" may be necessary in exceptional cases).

${ }^{2}$ See Shea, 17 Yale J Intl L at 131-32 (cited in note 23). See also Kester, 76 Georgetown L J at 1481 (arguing that "the State Department cannot be trusted to weigh the rights of individuals against the government's own international law enforcement and foreign policy agenda"); Wise, 15 Wayne $L$ Rev at 722-23 (cited in note 27) ("The question of whether a fugitive will meet with oppressive treatment is [not] suitable for consideration by executive departments, which are commonly influenced by a fear of offending some fairly despicable regimes.").

${ }_{93}$ Extradition Reform Act of 1981, Hearings on HR 5227 before the Subcommittee on Crime of the House Committee on the Judiciary, 97th Cong, 2d Sess 60 (1982) (statement of Professor Christopher H. Pyle).

94 Congress explicitly recognized this unique power of the courts when it enacted the Foreign Sovereign Immunities Act of 1976, Pub L No 94-583, 90 Stat 2891 , codified at 28 USC $\S \S 1330,1332(a)(2)-(4), 1391(f), 1441(d), 1602-11$ (1988). In that legislation, Congress 
The political offense doctrine and the exceptions courts have made to the noninquiry rule suggest that United States courts have already accepted the essential principle of liberalism in the context of extradition treaties: it is necessary to insure that the individual-sovereign relationship is intact before placing full faith in the sovereign as a valid representative of those individuals in the international sphere.

\section{Applying Liberal Theory to the Doctrine of Specialty: Guaranteeing Defendants' Due Process}

Like the political offense exception and exceptions to the noninquiry rule, the doctrine of specialty similarly functions to protect both individual and sovereign rights. The doctrine allows a signatory to an extradition treaty to escape the duties the treaty imposes when a crucial assumption underlying the treaty-that the other parties to the treaty can be trusted as legitimate representatives of the individuals within its control as well as protectors of due process rights-is no longer valid.

In most situations the interests of the sovereign and its individuals are not mutually exclusive. A state signs an extradition treaty in order to secure the return of fugitives from its own justice system, but it does not want to sacrifice its sovereign power entirely. Sovereign power includes the ability to extend asylum to fugitives from justice. Even when states limit this power by entering into extradition treaties, they retain the power to protect those individuals from indiscriminate prosecution in the requesting state. In this regard, the doctrine of specialty serves to guarantee that the essential contractual nature of the extradition agreement is upheld. In particular, the doctrine guarantees that the asylum country has given up its sovereign right to grant asylum only for the crimes mentioned in the initial extradition agreement and no others. Additionally, extradition treaties protect individual rights by providing procedures by which a requesting country can gain custody of a suspected criminal without resorting to kidnapping, exclusion, or deportation, which are more likely to ignore an individual's rights. ${ }^{95}$ The doctrine also serves to protect extradited individuals from indiscriminate pros-

decided to vest decisions about foreign state immunity in the courts rather than the State Department. See Thomas M. Franck, Political Questions, Judicial Answers: Does the Rule of Law Apply to Foreign Affairs? 104-06 (Princeton, 1992) (discussing the congressional history of this Act's passage).

${ }^{25}$ Gilbert, Aspects of Extradition Law at 4 (cited in note 14). 
ecution in the requesting country and to guarantee some semblance of due process.

In determining whether a defendant should have an independent right to allege specialty violations, courts must consider the relationship between the surrendering country and the people within its control. Courts often inquire into the democratic nature of foreign governments to determine whether to respect their internal domestic judgments. ${ }^{96}$ For example, in Biv Union Carbide Chemicals \& Plastics Co., Inc., the Second Circuit Court of Appeals upheld the lower court's decision to defer to India's judgment that disputes arising from the Bhopal accident in 1984 would best be resolved by granting the government of India itself exclusive standing to represent the victims of the mass tort in courts all around the world. ${ }^{97}$ The plaintiffs in the United States court sought damages from Union Carbide for the Bhopal accident and collaterally attacked the Indian government's settlement of their claims. ${ }^{98}$ The Supreme Court of India had upheld the Bhopal Act granting such broad powers of representation to the Indian government and excused the government's failure to give several thousand claimants notice of the settlement before its approval. ${ }^{99}$

Although the Second Circuit ultimately affirmed the lower court's decision to deny the plaintiffs standing, it did so only after a thorough examination of the nature of the Indian government. ${ }^{100}$ Implicit in the court's decision was the conclusion that the Bhopal Act was a valid law worthy of respect-even if it would have been held unconstitutional under the United States Constitution ${ }^{101}$ - because it was enacted by a democratic government. The court emphasized that India is a democracy with a constitution that "provides for a republican form of parliamentary government and guarantees the fundamental rights of the people, including equal protection and procedural due process." ${ }^{102}$ The decision suggests that had India's government been less demo-

961 Restatement of Foreign Relations $\$ 476$ comment h (cited in note 23). Courts have inquired into the domestic affairs of other nations in nonextradition contexts as well. For example, courts frequently undertake such inquiries when reviewing decisions of the Immigration and Naturalization Service concerning whether to grant political asylum in the United States to persons fearing persecution.

${ }_{97} 984$ F2d 582 (2d Cir 1993), cert denied, 114 S Ct 179 (1993).

98 Id at 585 .

99 Id.

100 Id at 585-86.

101 Id at 586.

102 Id at 585 . 
cratic, the court might not have approved India's method of dealing with the aftermath of this industrial accident. ${ }^{103}$

Like the $B i$ court, United States courts deciding whether to grant standing to individuals asserting specialty violations should inquire into the representative nature of the government of the surrendering state. The doctrine of specialty is a procedural right; although in many ways it functions to protect sovereign interests, it also serves to guarantee extradited defendants due process. In order to enforce this guarantee, United States courts should inquire whether the surrendering state does in fact represent the interests of its people.

It would be impractical and inefficient for the courts to engage in a full-scale inquiry into the political conditions in the surrendering country in every case in which the extradited individual attempts to invoke the doctrine of specialty. However, an inquiry into whether the surrendering state provides adequate procedural safeguards for individuals in its courts could serve as an efficient proxy determination. This inquiry would be much like the threshold inquiry in the application of the forum non conveniens doctrine which simply asks whether the foreign court will afford the parties due process. ${ }^{104}$ In making a forum non conveniens determination, one of the factors courts consider is the nature of the foreign state's government. ${ }^{105}$

Under the proxy test this Comment proposes, an individual who has been extradited from a country experiencing severe political turmoil or repression should have standing to assert the doctrine of specialty if the court determines that this turmoil prevented the surrendering state from adequately representing the individual. Examples of similar inquiries in forum non conveniens "adequate alternative forum" determinations are numerous. $^{106}$ In Walpex Trading Co. $v$ Yacimientos Petroliferos, the

103 See id at 586 ("India] decided in an act passed by its democratic parliament to represent exclusively all the victims in a suit against Union Carbide.") (emphasis added). See also id ("We are deferring to the statute of a democratic country to resolve disputes created by a disaster of mass proportions that occurred within that country.") (emphasis added).

${ }^{104}$ See Gulf Oil Corp. $v$ Gilbert, 330 US 501, 508 (1947).

105 See William L. Reymolds, The Proper Forum for a Suit: Transnational Forum Non Conveniens and Counter-Suit Injunctions in the Federal Courts, 70 Tex L Rev 1663, 166770 (1992).

${ }_{106}$ A similar inquiry is made in the field of choice of law. In Zschernig $v$ Miller, Justice Harlan wrote in his concurrence, " $[I] n$ the field of choice of law there is a nonstatutory rule that the tort law of a foreign country will not be applied if that country is shown to be 'uncivilized."” 389 US 429, 461-62 (1968). 
court noted that civil and political chaos in Bolivia might make Bolivia an inadequate forum. ${ }^{107}$ Similarly, in Rasoulzadeh $v$ Associated Press, the court held that Iran was not an adequate forum because if the plaintiffs returned to Iran to prosecute the claim, they would probably be shot. ${ }^{108}$

An extradited individual should also have standing to assert specialty if the court determines that the judicial system of the surrendering country does not provide due process to individuals in that country. An example of such an inquiry was present in the Bhopal litigation, in which the court questioned whether the foreign judicial system was reliable. ${ }^{109}$ Union Carbide contended that Indian courts did not observe due process standards that would be required as a matter of course in the United States. ${ }^{110}$ Another example of a similar inquiry is noted in Phoenix Canada Oil Co. Ltd. v Texaco, Inc., where the court found an alternative forum inadequate because of its political climate. The court noted that in order to be considered adequate, "the alternative forum must ... provide comparable procedural protections to those in the United States." 111

This threshold determination of due process is essential to ensuring that the asylum state adequately represents the individual. For example, the United States has treaties with some nations with reprehensible criminal procedures. In a 1984 House of Representatives report, Congressman Robert W. Kastenmeier and fourteen other congressmen pointed to (the former) Yugoslavia, Albania, Rumania, Bulgaria, Iraq, Turkey, Poland, and Haiti as examples of such countries. They noted that bilateral treaties existed with these countries prior to the ascendence of repressive regimes, and argued that the changes in government may call into question the abilities of these countries to assure the fundamental fairness of their legal systems. ${ }^{112}$ United States courts must not turn a blind eye to the political realities of the extradition process.

${ }^{107} 712$ F Supp 383, 393 (S D NY 1986)

${ }^{108} 574$ F Supp 854, 861 (S D NY 1983), aff'd, 767 F2d 908 (2d Cir 1985). See also Hatzlachh Supply, Inc. $v$ Savannah Bank of Nigeria, 649 F Supp 688, 692 (S D NY 1986) (The court acknowledged the plaintiff's argument that the alternative forum was inadequate in part "due to purported corruption.").

${ }^{109}$ In re Union Carbide Corp. Gas Plant Disaster, 634 F Supp 842, 847-53 (S D NY 1986), aff'd, 809 F2d 195 (2d Cir 1987).

110809 F2d at 204-05.

1178 FRD 445, 455 (D Del 1978).

112 HR Rep No 998 at 62 (cited in note 71). 
A determination that a foreign state does not adequately protect the rights of its citizens does not purport to condemn that state per se. Rather, the court merely has determined that the state should not be treated as a valid agent for the individual before the court. Liberal analysis recognizes a continuing and important role for states in the international system, but predicates recognition of that role by the judicial branch on minimum protections of human rights. This position preserves the independent role of the judiciary as a protector of individual rights in the international as well as domestic sphere, without unduly involving United States courts in political diplomacy.

\section{CONCLUSION}

It is time to step away from a theory of international law that regards the interests of states and individuals as necessarily divergent and mutually exclusive. As the Rauscher decision indicated over one hundred years ago, the doctrine of specialty protects the interests of an extradited individual as well as the interests of the asylum state. Other principles limiting the reach of extradition treaties-the political offense exception and other deviations from the traditional noninquiry rule-also serve to protect complicated mixtures of individual and sovereign interests. United States courts must respect the sovereign interests of other states, but they must also recognize that sovereigns should represent the interests of their people. When they fail to do that, the United States must become the guarantor of the defendant's right to due process and permit an extradited individual to raise the doctrine of specialty even without the support of the asylum state. 


\section{.}

